Studia Judaica 23 (2020), nr 2 (46), s. 390-404

doi:10.4467/24500100STJ.20.019.13662

Bella Szwarcman-Czarnota

\title{
Kadia Mołodowska
}

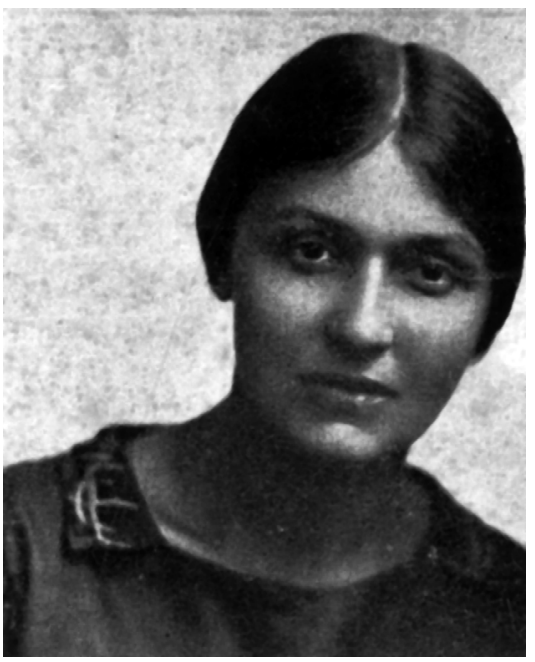

Kadia Mołodowska (1894-1975) była jedną z najwybitniejszych poetek jidyszowych, a także uważnie słuchanym głosem swego pokolenia ${ }^{1}$. Urodziła się w Berezie Kartuskiej, ale wiele jeździła: w poszukiwaniu edukacji, pracy, wreszcie - uciekając przed wojną i pogromami.

Przez dziesięć lat miejscem jej pracy i zamieszkania była Warszawa: nauczała w świeckich przedszkolach i szkołach żydowskich, publikowała

Kadia Mołodowska (lata dwudzieste XX w.)

Źródło: Jidisze dichterins. Antologie, red. Ezra Korman, Szikago 1928, s. 190 (ze zbiorów prywatnych).

${ }^{1}$ Niniejszy tekst został przygotowany na podstawie wstępu mojego autorstwa pt. „Forojs, majn arcybiografie / Naprzód, moja arcybiografio" do tomu: Kadia Mołodowska, Spadek po pradziadku. Opowieść, wstęp, tłum. i oprac. Bella Szwarcman-Czarnota (w przygotowaniu). Informacje dotyczące życia i twórczości Kadii Mołodowskiej podaję za: Anna Gonshor-Fishman, Kadye Molodowsky in "Literarisze Bleter" (1925-1935): Annotated Bibliography, A Thesis Submitted to the Faculty of Graduate Studies and Research in Partial Fulfillment of the Requirements of the Degree of Master of Arts, McGill University, Montreal 1997; Kathryn Hellerstein, Introduction, [w:] Paper Bridges: Selected Poems of Kadya Molodowsky, tłum. i oprac. Kathryn Hellerstein, Detroit 1999; Zelda Kahan-Newman, Kadya Molodowsky: The Life of a Yiddish Woman Writer, Washington 2018; Anita Norich, Introduction, [w:] Kadya Molodovsky, A Jewish Refugee in New York: Rivke Zilberg's Journal, Bloomington 2019. 
recenzje i wiersze w „Literarisze Bleter”, działała w Związku Pisarzy i Dziennikarzy przy ul. Tłomackie 13, brała udział w żydowskim życiu kulturalnym. Pierwszy tom jej wierszy pt. Cheszwendike necht [Noce miesiąca cheszwan] ukazał się w 1927 r. Choć poetka wzbraniała się przed określaniem jej twórczości jako kobiecej, w tym tomie i w dwóch następnych wypowiedziała się jako kobieta żydowska z krwi i kości - związana z tradycją, ale i zbuntowana wobec niej. Mołodowska była też wrażliwa na nierówności społeczne, czemu dała wyraz w kolejnym tomie wierszy Dzike gas [Ulica Dzika] z 1933 r. Szczególne miejsce w jej twórczości zajęły rymowane opowiastki dla dzieci - pisane z myślą o dzieciach z ubogich dzielnic Warszawy, a potem Nowego Jorku.

W 1935 r. poetka wyjechała z wykładami do Stanów Zjednoczonych, gdzie mieszkały już jej siostry oraz ojciec. Osiedliła się na stałe wraz z mężem, Symchą Lewem, w Nowym Jorku, gdzie pisała i wydawała kolejne tomy wierszy oraz powieści. Odwiedzała też większe skupiska żydowskie w Ameryce i Kanadzie.

W 1943 r. wraz z Icchokiem Baszewisem Singerem rozpoczęła wydawanie dwumiesięcznika literackiego „Swiwe”, jednak wieści o Zagładzie spowodowały, że odstąpili od tego projektu. Mołodowska intensywnie pisała, wydała m.in. powieść o adaptacji młodej imigrantki z Lublina do życia w Ameryce i tom wierszy powstałych w reakcji na Szoa - Melech Dowid alejn iz geblibn [Pozostał tylko król Dawid]. Po wojnie powitała z nadzieją powstanie Państwa Izraela, gdzie zamieszkała wraz z mężem na blisko trzy lata. Redagowała tam jidyszowe pismo „Hejm”, któremu patronowała lewicowo-syjonistyczna organizacja kobieca Moecet ha-Poalot. Po powrocie do Ameryki Mołodowska zajęła się redagowaniem nowej edycji „Swiwe” - tym razem jako kwartalnika i bez udziału Singera. Opublikowała też kolejne tomy wierszy oraz antologię poezji poholokaustowej. Zmarła w 1975 r.

Autobiografia Kadii Mołodowskiej Spadek po pradziadku. Opowieść ( $A$ majse fun majn elterzejdns jerusze) ukazywała się w odcinkach w czasopiśmie „Swiwe” w latach 1965-1974. Dominują w niej trzy wątki:

- Edukacja. Mołodowska wiele pisze o własnej edukacji - pod kierunkiem babki, ojca, prywatnych nauczycieli, wreszcie w Warszawie na pedagogicznych kursach hebrajskich. Czuje się pod tym względem kontynuatorką tradycji rodzinnej. Jej ojciec był nauczycielem, który chciał, żeby jego córka się uczyła; zachęcał ją i utwierdzał 
w słuszności obranej drogi. Pod koniec XIX i na początku XX w. nie była to w żydowskich małomiasteczkowych rodzinach postawa powszechna.

- Wspomnienia i opowieści o ludziach. Poetka deklaruje, jak ważna jest dla niej wspólnota celów i zainteresowań, którą nazywa swojskością. Szczególne miejsce zajmują spotkania z pisarzami. Mołodowska podkreśla niejednokrotnie, że własne pisarstwo jest dla niej ucieczką od rzeczywistości.

- Zmagania z przeciwnościami losu. Tu zawarte jest wszystko to, co poetka określiła jako ,żydowskie dramaty”: wojna, nędza, tułaczka. Spostrzeżenia Mołodowskiej jedynie w niewielkim stopniu odnoszą się do świata nieżydowskiego, wyraźna jest też jej niechęć do środowisk zasymilowanych.

Autobiografia kończy się na pobycie w Izraelu, gdzie Mołodowska jako redaktorka pisma „Hejm” jeździła po kraju, obserwując pracę ludzi oddanych budowie państwa.

Zamieszczone tu fragmenty czterech rozdziałów autobiografii Kadii Mołodowskiej stanowią ilustrację wyżej wymienionych tematów. W pierwszych dwóch rozdziałach poetka skupia się m.in. na formalnej i nieformalnej edukacji własnej. W trzecim opisuje spotkania z pisarzami, którzy zachęcili ją do tworzenia, wpłynęli na kształtowanie się jej postawy wobec pisarstwa. W drugim i trzecim rozdziale istotny jest ponadto wątek tułaczki wojennej i prób zapewnienia stabilizacji podopiecznym - dzieciom z domów dziecka. Czwarty rozdział poświęcony jest pierwszemu tomowi wierszy Mołodowskiej Cheszwendike necht, opublikowanemu w 1927 r., a także Związkowi Literatów i Dziennikarzy Żydowskich i funkcjonującym grupom poetyckim.

Bella Szwarcman-Czarnota email:bella@pro.onet.pl 


\section{Kadia Mołodowska Spadek po pradziadku. Opowieść (fragmenty) ${ }^{2}$}

\section{$\mathrm{Z}$ rozdziału: $W$ warszawskim „Hazomirze”}

W pewien wieczór szabatowy, kiedy nie było żadnych zajęć, moja koleżanka Gulce i ja poszłyśmy do „Hazomiru” posłuchać Pereca. Sala była nieduża. Wszystkie miejsca były zajęte. Ludzie stali pod ścianami, a nawet na krzesłach. Panował uroczysty nastrój. Czekano na przybycie Pereca. Wszedł w towarzystwie dwóch młodych pisarzy. [...]

Perec mówił o teatrze jidysz. Jedno jego powiedzenie zapadło mi w pamięć. Podkreślił: „Aktor nie powinien wychodzić na scenę z »brudnymi paznokciami «". Chodziło mu o to, że aktor powinien reprezentować pewien poziom kultury. Zaproponował teatr idei, nie „śpiewogrę”. Publiczność chłonęła każde jego słowo. Po prostu zaczarował ludzi.

Odtąd często wpadałam do „Hazomiru”. U nas na kursach studiowało się historię Żydów, Tanach, hagady, literaturę hebrajską. Te wszystkie przedmioty odnosiły się mniej lub bardziej do przeszłości. Wyszukiwano wielkich Żydów z minionych pokoleń, którzy kształtowali naród żydowski, jego moralność, obyczajowość, żydowskiego ducha i męstwo w stawianiu oporu. W „Hazomirze” mówiono w języku jidysz o tym, co dzieje się obecnie - o teatrze, asymilacji, Żydach religijnych i świeckich. Miałam teraz dwie nowe żydowskie bramy i obie prowadzily do tej samej ulicy. Było dla mnie rzeczą naturalną, że chodzę obiema bramami, podobnie jak u nas w Berezie, gdzie studiowano Pięcioksiąg i gdzie mówiono w jidysz. W budynku, w którym mieścił się „Hazomir”, było gwarno wieczorami, gdy odbywały się odczyty. Ludzie stali pod drzwiami, gawędząc. Było jak w bóżnicy przed modlitwą. W niewielkiej sali również panowała atmosfera bóżnicznej pobożności. Nie były to w żadnym razie spotkania dla rozrywki, lecz raczej rodzaj wolnego uniwersytetu.

W „Hazomirze” zetknęłam się z nauczycielem jidysz, Gilińskim³. Kierował, jak mi się zdaje, pierwszą jidyszową szkołą w Warszawie. Interesował

2 Tom wspomnień Kadii Mołodowskiej, z którego pochodzi niniejszy fragment, ukaże się w serii „Żydzi. Polska. Autobiografia” pod tytułem Spadek po pradziadku. Opowieść w thumaczeniu z jidysz i opracowaniu Belli Szwarcman-Czarnoty (Warszawa 2021, w druku). Przekład został dokonany na podstawie odcinków opublikowanych w kwartalniku „Swiwe” od marca 1965 do kwietnia 1974 r. pod tytułem A majse fun majn elterzejdns jerusze.

${ }^{3}$ Szlojme Giliński (1888-1961) - pedagog w szkołach świeckich Szmuela Lejba Gordona i Jechiela Halperna, dyrektor elementarnej szkoły dla dzieci z uboższych domów 
się naszymi kursami i wypytywał mnie, czego u nas nauczają i co robi się z dziećmi z przedszkola przed południem. Nie wykazywał żadnej niechęci wobec hebrajskich kursów. My, uczennice kursów, nigdy nie myślałyśmy w kategoriach sporu języków, wojny między językami.

\section{$Z$ rozdziału: Chmury nad zydowskimi dachami}

Gdy z wielkim zapałem wróciłam do Warszawy, do nauki na drugim roku kursów, by potem z młodzieńczą pasją zabrać się do wychowywania żydowskich dzieci, okazało się, że nikt nie jest panem swoich marzeń. Budujemy zamki na lodzie, a one topnieją. Los jednostek i los społeczności nie jest w naszych rękach. Gdy jesteśmy starsi, wiemy to już z licznych doświadczeń, ale w młodości jest to trudne przeżycie.

Wybuchła pierwsza wojna światowa. Ciężkie chmury rozsnuły się nad nami, przede wszystkim nad żydowskimi dachami. Zaczęła się tułaczka zrujnowanych rodzin, które mieszkały w pobliżu linii frontu. Ci, którzy byli zamożni, zubożeli; nazywano ich wówczas bieżeńcami.

Na kursach zajęcia odbywały się jak dawniej. Uczyłyśmy się, czytałyśmy, szykowałyśmy się do egzaminów, ale ziemia pod naszymi stopami już zaczęła dygotać. Pierzchła nadzieja na założenie nowych przedszkoli, nowej szkoły. Nikt nie wiedział, co przyniesie jutro, dokąd rzuci nas los.

I to los sprawił, że za młodu rozpoczęłam naukę historii Żydów, czerpiąc ją z samego życia, z wydarzeń, które nastąpiły w ciągu dwóch lat mojej nauki na kursach. Pierwszy rok nauki w Warszawie upłyną pod znakiem procesu Bejlisa ${ }^{4}$. Polowania na całe pokolenie Żydów były coraz bardziej przerażające - zamieszki, prześladowania i żydowskie cierpienie. Drugi rok - to była pierwsza wojna światowa. Żydzi porzucali swoje miasta i miasteczka, wędrowali, przeżywali męki, trzeba było ich wydobywać z nędzy i bezdomności. To karty żydowskiej historii, które jako dwudziestolatka gruntownie przerobiłam. Odczułam otchłań pod stopami pokoleń.

„Chinuch jeladim” (Edukacja dziecięca). Wraz z m.in. Icchokiem L. Perecem i Jakubem Dinezonem założył pierwszy dom dziecka o nazwie „Pereces kinderhejm” (Perecowski dom dziecka). Był działaczem związku zawodowego nauczycieli żydowskich. Studiował we Wszechnicy Polskiej, był też jednym z założycieli CISzO. W latach 1926-1939 pełnił funkcję dyrektora do spraw pedagogicznych w Sanatorium im. Medema w Miedzeszynie.

${ }^{4}$ Menachem Mendel Bejlis (1874-1934) - rosyjski Żyd aresztowany w 1911 r. i oskarżony o popełnienie mordu rytualnego. Proces odbył się w 1913 r. i zakończył się uniewinnieniem Bejlisa. W jego obronie wystąpili m.in. Maksym Gorki i Aleksander Błok. Uwięzieniu i procesowi towarzyszyła propaganda antysemicka i niebywały, światowy rozgłos. Jednakże Bejlis był ostatnim Żydem - dotychczas - oskarżonym o popełnienie morderstwa w celach rytualnych. Po uwolnieniu wyjechał do Palestyny, a następnie do Stanów Zjednoczonych. 
Na kursach organizowano uroczyste obchody żydowskich świąt Chanuki, Purim, tak jak przed rokiem. Wszystko wokół nas się chwiało, ale mieliśmy żydowską wytrwałość i wytrzymałość. Świętujemy dawne ocalenia i mamy nadzieję na nowe. Wszystkie nasze wesołe święta odbieraliśmy jako znaki i świadectwa żydowskiej wytrwałości.

Pojawiły się pogłoski, że nasze kursy zostaną przeniesione z Warszawy do Odessy. To daleka wędrówka, ale praca i nadzieja pozostaną. Jednym słowem, trzeba przenieść górę Synaj z jednego krańca świata na drugi. I czynimy to.

W Warszawie różne organizacje żydowskie zaczęły tworzyć domy dla bezdomnych dzieci. Perec był, jak wiadomo, niezmiernie oddany pracy w organizowaniu owych tymczasowych instytucji pomocy dzieciom. Dyrektor naszych kursów Jechiel Halperin, rzecz jasna, także włączył się do dzieła. W tym roku miał już zupełnie inne kłopoty - nie te radosne, takie jak organizowanie hebrajskich przedszkoli w wielu miastach, początek szkół, lecz trudne zadanie pozyskiwania funduszy, szukania mieszkań, wspierania działalności domów dziecka w Warszawie, żeby móc dać bezdomnym dzieciom zarówno jedzenie, jak i zabawę.

Do Warszawy napłynęło wiele bezdomnych rodzin żydowskich mieszkających w pobliżu linii frontu. Tułacze gromadzili się na dziedzińcu żydowskiej gminy warszawskiej. Nie było żadnej różnicy między bogatymi a biednymi. Raptem wszyscy stali się równi, bez dachu nad głową, bez środków utrzymania, bez pracy. Historia Żydów została napisana nie na papierze, ale na twarzach tych bezdomnych. Tułaczka, to niegdysiejsze wygnanie z Niemiec, wypędzenie z Anglii, z Hiszpanii. Raptem stanęły nam przed oczami wędrówki wszystkich pokoleń Żydów.

Dyrektor naszych kursów, Jechiel Halperin, uzyskał lokal na zorganizowanie domu dziennego pobytu dla bezdomnych dzieci. Wyznaczył mnie do pracy w tym domu. Przebywały w nim dzieci w różnym wieku, pięcio-, sześcio-, a nawet dziesięcioletnie. Pracowała ze mną jeszcze jedna nauczycielka. Miała na imię Eliza. Obecnie nazywa się Eliza London i mieszka w Izraelu. Jechiel Halperin odbył z nami rozmowę na temat szczególnego sposobu pracy z bezdomnymi dziećmi. Najważniejsze było, wyjaśnił nam, żeby dzieci poczuły się w tym domu jak u siebie mimo swojej bezdomności. To była istota pracy pedagogicznej w domu dziecka. [...]

Od czasu do czasu do domu dziecka przychodziła czyjaś matka lub ojciec, żeby popatrzeć na swoje dzieci. Od nich nasłuchałyśmy się, jak został zniszczony ich dobytek, zburzono domy, a nierzadko widziałyśmy łzy 
w ich oczach. Żydowskie dramaty stanęły nam jak żywe przed oczami. Całe szczęście, że w domu dziennym dzieci tego nie odczuwały. Ratowaliśmy je.

Jedną z organizacji pomagających utrzymać dom dzienny dla bezdomnych dzieci był Żydowski Komitet Pomocy (Je.Ko.Po.)5. Pewnego dnia przyszedł do nas z wizytą Fiałkow, przewodniczacy tego komitetu. Zachowywał się bardzo spokojnie. Nieco arystokratycznie i bardzo po żydowsku. Nie rozumiałam, dlaczego mówił do nas po rosyjsku, chociaż nie robił wrażenia inspektora, lecz Żyda, który współodczuwa cierpienie innych Żydów. Do dziś mam przed oczami jego kiwanie głową, kiedy mówiłyśmy mu o pracy z dziećmi i przytaczałyśmy to, co opowiadali nam ich rodzice. Jego przytakiwanie wyrażało cierpienie człowieka, który zna dobrze żydowski los i wie, że mamy za sobą długą, bolesną historię.

Nasz dom dziennego pobytu znajdował się naprzeciwko Ogrodu Krasińskich, w żydowskiej dzielnicy. Wychodziłyśmy z dziećmi na spacer i zabawy w Ogrodzie. Na ławkach siedzieli mężczyźni w chasydzkich strojach i malutkich czapeczkach na głowach. Gawędzili, targowali się, hałasowali, „mówili rękami”. Oni wszyscy wyglądali w moich oczach jak bezdomni. W tej chwili są tutaj, ale w następnej ktoś może ich wypędzić. Praca z bezdomnymi dziećmi była moją pierwszą nauczycielską posadą po ukończeniu kursów. Z bezdomnymi dziećmi tułaczego ludu. To dało mi głębokie zrozumienie żydowskiej historii, której uczyłyśmy się na kursach.

Dzieci w naszym domu dziennym stale się wymieniały. Wiele spośród przybyłych rodzin rozjechało się do różnych miast i miasteczek do krewnych, inni pojechali do miejscowości, w których dostali pracę. Na miejsce tych dzieci, które wyjechały, przybywały inne dzieci. Linia frontu przybliżyła się do Warszawy. Pod koniec lata dom dzienny został zamknięty. Nasze kursy przeniesiono do Odessy. Pojechałam do domu, żeby zobaczyć się $\mathrm{z}$ rodziną.

Kiedy przyjechałam do domu, w naszym miasteczku także zebrało się wiele tułających się rodzin. Oczywiście u nas nie było zorganizowanej pomocy takiej jak w Warszawie, ale były niewielkie grupki, które pomagały bezdomnym. Ta miłość zwykłych ludzi do ludu Izraela była odczuwalna na każdym kroku.

${ }^{5}$ Pełna nazwa: Jewriejskij Komitiet Pomoszczi Żertwam Wojny (ros.) (Żydowski Komitet Pomocy Ofiarom Wojny) - organizacja założona w 1915 r. na terenie Imperium Rosyjskiego. 


\section{$\mathrm{Z}$ rozdziału: Dawid Bergelson ${ }^{6}$ publikuje moje pierwsze wiersze w almanachu „Ejgns"}

W Kijowie spodziewano się pogromu. Władza przeszła z rąk do rąk. Moja znajoma, dentystka, zaproponowała mi, żebym przyjechała i przetrwała u niej ten niespokojny czas. Mieszkała w eleganckiej okolicy, na Kreszczatiku. Była pewna, że w tej części miasta nie będzie żadnego pogromu. Zaprosiła także innych przyjaciół. Wszyscy byliśmy młodzi, więc było nam razem wesoło.

Pewnego ranka usłyszeliśmy mocne uderzenie w drzwi. Zrozumieliśmy, że to niepożądani goście. Nie było innego wyjścia - gospodyni otworzyła drzwi. Weszło czterech dziarskich młodych oficerów. Nie powiedzieli „dzień dobry”, lecz rozkazali: „Oddajcie pieniądze (dien'gi dawajtie)”. Siedzieliśmy wówczas przy stole i jedliśmy śniadanie. Żeby nas popędzić, byśmy szybciej im dali pieniądze, wyjęli rewolwery z kabur. Jeden z nich podszedł do mnie i przyłożył mi rewolwer do serca. Nie odczuwałam lęku (zapewne byłam już martwa ze strachu). Prorok Eliasz najwyraźniej nadal mnie chronił - oficer nacisnął spust, ale rewolwer nie wystrzelił. Ten człowiek miał piękną, subtelną twarz. Do dziś nie mogę pojąć, jak ktoś może stać się „pogromszczykiem”. Młodzieńcy zabrali nam pierścionki, zegarki i pieniądze, które posiadaliśmy. Nie omieszkali zapytać dentystkę, czy ma zapas złotych zębów. Krótko mówiąc, wszystko to elegancko wsunęli do kieszeni i poszli. Byli „przyzwoitymi ludźmi” - nikogo nie pobili, nie pieklili się, lecz poszli sobie. Co prawda, bez pożegnania, ale zamknęli za sobą drzwi - i tyle. Gdy już byłyśmy same, my, okradzione dziewczyny, wychwalałyśmy ich, że okazali się całkiem porządnymi ludźmi - w końcu nie posłali nas na tamten świat. Codziennie nasze życie wisiało na włosku. Dziękowałyśmy Bogu, że jeszcze jeden dzień minął - i jakoś przeżyłyśmy.

I znów zmieniła się władza. Bandy napastników zostały przepędzone. W mieszkaniu dentystki urządziłyśmy małe przyjęcie z tej okazji, że wszystkie ocalałyśmy z pogromu. Na tę okoliczność napisałam wesołą „pieśń pochwalną” dla „pogromszczyków”. Opisałam, jak uroczyście są

${ }^{6}$ Dawid Bergelson (1884-1952) - jeden z najwybitniejszych pisarzy prozaików tworzących w jidysz, działacz Żydowskiego Komitetu Antyfaszystowskiego, oskarżony przez władze radzieckie o szpiegostwo, szerzenie wrogiej propagandy i nacjonalizm żydowski; został stracony wraz z innymi pisarzami i działaczami żydowskimi podczas tzw. nocy zamordowanych poetów 12 sierpnia $1952 \mathrm{r}$.

7 „Ejgns” - almanach literacki, który ukazał się w dwóch edycjach (1918 i 1920), redagowany przez Dawida Bergelsona i Der Nistera, wydawany i rozpowszechniany przez Kultur Lige w Kijowie. W „Ejgns” publikowali przede wszystkim pisarze z tzw. Grupy Kijowskiej, tworzącej w jidysz, hołdującej modernizmowi, apolitycznej. 
przyjmowani w raju i cadykowie wydają im zaświadczenia. Na to przyjęcie przyszedł brat Der Nistera ${ }^{8}-$ Kahanowicz ${ }^{9}$. Był malarzem. Goście śmiali się, gdy czytałam pieśń pochwalną na cześć „pogromszczyków”. Kiedy ją przeczytałam do końca, Kahanowicz wyrwał mi z ręki zeszyt i włożył do kieszeni - chciał to pokazać swojemu bratu Der Nisterowi. W tym zeszycie znajdowały się też inne moje wiersze. Pisałam je jeszcze w dzieciństwie; to była moja zabawa. Nawet gdy podrosłam, nie przychodziło mi do głowy, żeby je komukolwiek pokazać albo dać do druku. Prosiłam Kahanowicza, żeby mi zwrócił zeszyt. Krępowało mnie to, że ktoś zobaczy moją zabawę w pisanie wierszy. Kahanowicz upierał się przy swoim i zabrał zeszyt. Kilka tygodni później oznajmił, że Der Nister pokazał te wiersze kilku pisarzom i że oni chcą się ze mną spotkać. Wymienił mi nazwiska Bergelsona, Der Nistera, Dobruszyna. Nie poszłam. Nie przyszło mi na myśl, że mogłabym stać się częścią tego „niebiańskiego świata” pisarzy. Myślałam, że książki otrzymuje się na górze Synaj.

W owym czasie pracowałam z kilkoma nauczycielkami w domu dla dzieci z pobliskich miasteczek. Żydzi uciekli stamtąd z powodu pogromów. Jedna z nauczycielek domu dziecka była krewną Bergelsona. Pewnego pięknego dnia podeszła do mnie i powiedziała, że Bergelson był u niej i powiedział, że chce się ze mną spotkać. Kiedy do niego poszłam, zapytał, dlaczego nie przyszłam, kiedy mnie zaproszono. Umówił się ze mną, kiedy i gdzie mamy się spotkać. W wyznaczonym dniu wystroiłam się i poszłam na spotkanie. Odbyło się ono w domu Bergelsona. Przyszło tam kilku pisarzy oprócz Bergelsona byli obecni Der Nister, Dobruszyn ${ }^{10}$ i Lejb Kwitko ${ }^{11}$. Grupa żydowskich pisarzy, która wówczas przebywała w Kijowie, miała

${ }^{8}$ Der Nister (z hebr. 'ukryty'), właśc. Pinchas Kahanowicz (1884-1950) - jeden z najwybitniejszych pisarzy tworzących w jidysz, filozof, krytyk i tłumacz. W swojej twórczości inspirował się mistycyzmem, chasydyzmem, kabałą, jak również opowiadaniami Nachmana z Bracławia. Tworzył w duchu symbolizmu; poddany surowej krytyce radzieckich urzędników od literatury, próbował pisać zgodnie z zasadami realizmu. Jego największym i niedokończonym dziełem była saga Di miszpoche Maszber [Rodzina Maszberów]. Zmarł w nieznanym więzieniu.

${ }^{9}$ Max, właśc. Motl Kahanowicz - młodszy brat pisarza Pinchasa; był rzeźbiarzem i marszandem zamieszkałym w Paryżu.

${ }_{10}$ Jechezkiel Dobruszyn (1883-1953) - jeden z założycieli Kultur Lige w Kijowie, wykładowca języka jidysz na uniwersytecie i w seminarium nauczycielskim. Publikował w piśmie „Ha-Cefira”, a także w czasopiśmie „Wochnblat”. Był pierwszym sekretarzem Żydowskiego Związku Pisarzy w ZSRR. Jako dramaturg tworzył repertuar dla Żydowskiego Teatru Państwowego. Był niezwykle płodnym pisarzem, a także członkiem Żydowskiego Komitetu Antyfaszystowskiego. Zmarł prawdopodobnie na zesłaniu.

${ }^{11}$ Lejb Kwitko (1893-1952) - poeta liryk, jeden z najwybitniejszych poetów tworzących w jidysz dla dzieci. Początkowo działał w Kijowie, następnie w Charkowie. W Moskwie od 
zamiar wydać drugi tom almanachu „Ejgns”. Tam właśnie miały po raz pierwszy ukazać się drukiem moje wiersze. Powiedziałam do Bergelsona: „Co będzie, jeżeli już nigdy nie napiszę żadnego wiersza? Ludzie będą się ze mnie śmiać. Powiedzą: »Napisała kilka wierszy i na tym koniec«". Bergelson uśmiechnął się i rzekł: „Nikt nie zaczyna od końca, wszyscy zaczynają od początku”.

Dobruszyn spisał mi długą listę książek, które mam przeczytać. Prawdę powiedziawszy, nigdy nie użyłam tej listy. Bergelson zażartował, że pisarz nie uczy się z książek. On chodzi do swojej własnej szkoły. Wyszłam z tego spotkania z pisarzami lekko zdziwiona. Ni stąd, ni zowąd wydrukują mnie w „Ejgns”.

Ta grupa pisarzy w Kijowie, która wydawała almanach „Ejgns”, składała się ze znanych już pisarzy. Powieść Bergelsona Noch alemen [Po wszystkim] uczyniła go sławnym i wielkim artystą jeszcze przed pierwszą wojną światową. Der Nister był już także uznanym pisarzem. Młodsi pisarze - Dawid Hofsztejn ${ }^{12}$, Perec Markisz ${ }^{13}$, Lejb Kwitko - mieli również swoje miejsce jako uznani poeci. Spotkałam wtedy Nachmana Majzila ${ }^{14}$, późniejszego redaktora „Literarisze Bleter” ${ }^{15}$ w Warszawie. Wszystkich tych pisarzy

1936 r. był członkiem Żydowskiego Komitetu Antyfaszystowskiego. Stracony podczas „nocy zamordowanych poetów".

12 Dawid Hofsztejn (1889-1952) - poeta, który tworzył od dziewiątego roku życia, najpierw po ukraińsku, rosyjsku, po hebrajsku, zanim zaczął pisać w jidysz. Pracował jako nauczyciel prywatny. Po rewolucji bolszewickiej umocniły się jego lewicowe przekonania. Działał w Kultur Lige. Początkowo chwalony przez komunistyczną krytykę jako „poeta narodowy”. Popadł w niełaskę, gdy podpisał memoriał w sprawie przywrócenia nauki języka hebrajskiego, jednak przetrwał czystki z lat trzydziestych. Wraz z innymi członkami Żydowskiego Komitetu Antyfaszystowskiego został aresztowany w 1948 r. i zamordowany w 1952 r.

${ }_{13}$ Perec Markisz (1895-1952) - poeta, prozaik, dramaturg tworzący w jidysz, debiutował jednak wierszami pisanymi po rosyjsku. W czasie swojego kilkuletniego pobytu w Warszawie wraz z innymi poetami modernistycznymi Urim Cwim Grinbergiem i Melechem Rawiczem działał w awangardowej grupie „Chaliastre”. Był też współzałożycielem czasopisma literackiego „Literarisze Bleter”. W 1926 r. osiedlił się w ZSRR, stając się jednym z najważniejszych radzieckich poetów jidysz, jako jedyny też otrzymał Order Lenina. Aresztowany w 1949 r., został stracony wraz z innymi członkami Żydowskiego Komitetu Antyfaszystowskiego w $1952 \mathrm{r}$.

${ }^{14}$ Nachman Majzil (Majzel) (1887-1966) - jeden z najbardziej wpływowych krytyków literackich, publicysta i wydawca, m.in. współwydawca „Literarisze Bleter”. Uczestniczył w paryskim żydowskim światowym kongresie kultury w 1937 r., kiedy powołano do życia JIKUF - Jidiszer Kultur Farband (Stowarzyszenie Kultury Żydowskiej). Po wyemigrowaniu do Stanów Zjednoczonych Nachman Majzil został wydawcą miesięcznika JIKUF - „Jidisze Kultur".

15 „Literarisze Bleter” - najważniejszy tygodnik literacki w języku jidysz, wydawany w Warszawie od 1924 r. do połowy 1939 r. pod redakcją Nachmana Majzila i Melecha Rawicza. Publikowali w nim najwybitniejsi żyjący wówczas pisarze i poeci, również wyżej wymieniony Perec Markisz. 
łączyły przyjazne stosunki. Niemniej jednak czułam, że weszłam w nowe środowisko i że pisarstwo jest odpowiedzialnym zadaniem. [...]

Bergelson nigdy nie udzielał mi rad, jak mam zmienić konkretny wers w wierszu. Według niego, jak się zdaje, pisarz musi „chodzić do swojej własnej szkoły”. Dodał mi jednak wiele energii. Dał mi do zrozumienia, że nie powinnam zanadto zajmować się innymi sprawami, lecz przede wszystkim poświęcić się pisaniu.

Do Bergelsona często przychodzili Markisz, Kwitko i Hofsztejn. W moich oczach Markisz i Hofsztejn stanowili dwa odrębne światy. Markisz był hałaśliwy, żywy i lubił wtrącać różne powiedzonka. Hofsztejn był milkliwy, cichy, rzadko było słychać, żeby coś mówił. Z Lejbem Kwitką czułam się bardziej swojsko niż z tamtymi. Pewnego razu szłam z nim ulicą. Zaczął lać ulewny deszcz. Przystanęliśmy pod balkonem, żeby przeczekać, aż przestanie padać. Gawędziliśmy o pisaniu wierszy. Pozostało mi w pamięci jego powiedzenie: „Wie pani, poeci są czarodziejami. Zmieniają wyobrażenia w żywy świat. Można pisać o ptaku, który złamał skrzydło, a zobaczyć los człowieka w jego nieszczęściu i bezradności”.

Kwitko był poetą z krwi i kości.

Z okazji ukazania się almanachu „Ejgns”, do którego weszły moje wiersze, zorganizowano wieczór. Zaproponowano mi, żebym wystąpiła na tym wieczorze i przeczytała kilka swoich utworów. Nie byłam pewna, czy powinnam to zrobić - jak to, mam stanąć przed publicznością i czytać swoje wiersze? Powiedziałam Bergelsonowi, że nie mam ochoty wystąpić. Bergelson dodał mi otuchy. Po długim namyśle przeczytałam wiersze, stojąc przed publicznością. Mój występ przyjęto bardzo dobrze. Poczułam wtedy, że wiersz nie jest własnością twórcy, lecz należy do wszystkich. Pisarz jest człowiekiem jak inni, ale też pisze: opowiadania albo wiersze. Jednym słowem, pojęłam, że pisze się dla ogółu.

Często przychodziłam do Bergelsona do domu. Tam spotykałam innych pisarzy, którzy też u niego bywali. Pozostało mi w pamięci drobne zdarzenie. Pewnego razu Bergelson przeczytał nam rozdział z opowiadania, które wówczas pisał. On czytał, a ja widziałam bohaterów opowiadania tak, jakby stali przede mną żywi. W jego czytaniu była pewna intymność, bliskość wobec ludzi, których opisuje. Miało się wrażenie, że nie jest to zmyślona historia, ale przeżyta, płynąca z głębi duszy.

Spotkania z Bergelsonem stymulowały mnie do zrozumienia natury pisarstwa. Czułam, że pisanie nie szybuje hen wysoko, w górze, lecz ma swoje korzenie w naszym „wyposażeniu”. 


\section{Z rozdziału: Mój pierwszy tom wierszy: „Cheszwendike necht”}

Napisałam już sporo wierszy, więc chciałam wydać swój pierwszy tom Cheszwendike necht. W owych czasach wydanie książki nie było problemem. Poszłam do Borysa Kleckina ${ }^{16}$, powiedziałam mu, że mam sporo wierszy i chciałabym je opublikować. Jego wydawnictwo było poważną instytucją. Sam Kleckin był zamożnym człowiekiem, który miał - by tak rzec kaprys, żeby wydawać książki żydowskie. Nie musiał na tym zbijać majątku. Może nawet wprost przeciwnie: dokładał do wydawnictwa swój majątek. Najważniejsze było dla niego wydawanie żydowskich książek - dobrych żydowskich książek. Chciał uczynić wydawnictwo „Kleckin” centralną instytucją literatury żydowskiej. Kleckin przechadzał się po pokoju niczym król po swoim królestwie. Nie spodziewałam się, że wszystko przyjdzie mi tak łatwo. Nie rozmawiał ze mną długo. Powiedział krótko: „Dobrze, proszę przynieść rękopis".

Kilka miesięcy później został opublikowany tom Cheszwendike necht. Książka ta została bardzo dobrze przyjęta. Ukazało się kilkadziesiąt recenzji w rozmaitych gazetach i czasopismach zarówno w Polsce, jak i w Ameryce. Chociaż była to moja pierwsza książka, nie czułam się jak debiutantka. Książka to książka. Pisanie wierszy było dla mnie przede wszystkim wyrzuceniem z siebie tego, co leżało mi na sercu. W ciągu dnia byłam zajęta pracą w szkole. Wiersze pisałam przeważnie wieczorami. Ubóstwo, w jakim żyła społeczność żydowska, ograniczenia związane z pracą ciążyły mi niezmiernie. Podczas pisania wierszy zdarzało mi się uronić łzę. Ukazanie się książki nie było dla mnie świętem, dominowało uczucie ulgi, rozładowania napięcia. W owym czasie napisałam wiersz, który zaczynał się następująco:

Nie piszę wiersza,

próbuję

znaleźć słowo dla krwi,

co płacze w moim ciele ${ }^{17}$.

Przypomina mi się historia o tych kilku linijkach. Jakiś czas po ukazaniu się mojej książki Cheszwendike necht do Warszawy przyjechał H. Lejwik ${ }^{18}$.

${ }^{16}$ Borys Kleckin (1875-1937) - wydawca wileński i działacz Bundu. Założył wydawnictwo w 1910 r. pod nazwą Wilner Farlag fun B. Kleckin. Publikował książki i pisma w jidysz, przekłady, a także literaturę naukową.

${ }_{17}$ Zob. Kadia Mołodowska, Marsz, [w:] ead., Dzike gas, Warszawa 1933, s. 10.

${ }^{18}$ H. Lejwik, właśc. Lejwik Halpern (1888-1962) - poeta tworzący w jidysz, dramaturg, autor jednego z najbardziej znanych dramatów teatru jidysz pt. Golem. Jeszcze w Rosji zbliżył się do socjalistycznej partii Bund. Skazany na cztery lata zesłania na Syberię, zdołał stam- 
Kiedy się spotkaliśmy, zacytował mi z pamięci te cztery linijki z mojego wiersza. Byłam zdumiona tym, że je zapamiętał. Lejwik uśmiechnął się po swojemu i powiedział: „To są strofy dotyczące każdego poety - głos idący od wewnątrz". [...]

W Związku Literatów dużo się działo. Powstała grupa prozaików i poetów, którzy nadali sobie nazwę „Chaliastre”19. Należeli do niej: Perec Markisz, Melech Rawicz, I. J. Singer i inni. Ja sama nigdy nie należałam do żadnej grupy literackiej. Mam wrażenie, że każdy pisarz lub poeta jest dla siebie ben joched ${ }^{20}$, ma swój styl, własny, osobny świat, taki, jak go postrzega, albo - ściślej - jaki sobie wymarzył. Między pisarzami może istnieć koleżeństwo, ale grupa literacka pod wspólną nazwą jest niemożliwa. Kiedy krytycy rozpatrują jakąś grupę pisarzy jako całość i nazywa się ją „Chaliastre” albo „Di Junge”21, albo „Inzichistn”22, albo jakoś inaczej, nie można ich w żaden sposób porównywać. Każdy pisarz podąża swoją drogą, na własny sposób, i nie można pisarzy wrzucać jak fasolki do jednego worka.

Rawicz na przykład pisał po swojemu, przedstawiając swoje filozoficzne podejście do świata - zawsze rozpatrywał wszystko z każdej strony. Poszukiwał sensu ludzkiego losu, natury Boga i wieczności. Taka była jego droga. Z bulwersującym słowem „Chaliastre” nie ma to żadnego związku, ale „pożeniono” go z „Chaliastre”.

Albo na przykład amerykańska grupa pisarzy „Di Junge”: Mojsze Lejb Halpern ${ }^{23}$ był wcieleniem rewolty, zrywu $-\mathrm{z}$ innych czasów i z innego

tąd uciec i przedostać się do Stanów Zjednoczonych. Był członkiem grupy poetyckiej „Di Junge" (Młodzi). Wraz z Josefem Opatoszu opublikował wiele antologii literatury jidysz.

19 „Chaliastre” (Hałastra) - działająca w latach dwudziestych XX w. awangardowa grupa artystyczno-literacka, a także almanach wydawany przez tę grupę. Oprócz wymienionych w tekście do grupy należeli Uri Cwi Grinberg i Mojsze Broderzon.

${ }^{20}$ Ben jachid (hebr.) lub ben joched (jid.) - 'jedyny syn'.

21 „Di Junge” (Młodzi) - grupa poetów piszących w jidysz, działająca w Ameryce, jej członkowie pochodzili z Europy Środkowo-Wschodniej. Czerpali z niemieckiego ekspresjonizmu i z rosyjskich symbolistów. Poeci tej grupy głosili prymat wartości estetycznych nad społecznymi i narodowymi w sztuce. Do grupy należeli m.in.: Mani Lejb, Zisze Landau, Icyk Manger, Aron Cejtlin.

${ }^{22}$ „Inzichistn” (od jid. In Zich 'w sobie') - introspektywiści, grupa, która nastąpiła po „Di Junge” w 1919 r., skupiając się wokół pisma „In Zich”. Założycielami grupy byli m.in. Aron Glanc-Lejeles, Jankew Glatsztejn i inni. W zgodzie z nazwą poeci wzywali do spojrzenia w głąb siebie samych, deklarowali: „świat istnieje tylko poprzez nas i w nas”.

${ }^{23}$ Mojsze Lejb Halpern (1886-1932) - modernistyczny poeta tworzący w jidysz, jednak pierwsze wiersze pisał po niemiecku. Zamieszkał w Nowym Jorku w 1908 r., gdzie został aktywnym członkiem grupy „Di Junge”; jeden z najbardziej wszechstronnych poetów, liryk, a zarazem kpiarz i prześmiewca, piewca wielkiego miasta, ale i tęsknoty za małym miasteczkiem. 
środowiska. W swoim tomie Nju Jork [Nowy Jork] zamieścił wiersz Undzer gortn [Nasz ogród] o drzewie, na którym rośnie siedem liści. Poeta postrzegał żydowski „ogród” wraz ze wszystkimi ograniczeniami, ubóstwem i odgradzaniem się od otoczenia. Taka była jego droga. Ale niemal w tym samym czasie H. Lejwik napisał Golema, który obrazuje nie tylko epokę Maharala ${ }^{24}$, lecz wieczne żydowskie zmagania i poszukiwania ratunku wszędzie dokoła. To nie ma nic wspólnego z „młodością”, lecz jest tak stare, jak stara, odwieczna jest żydowska droga i dążenie do ocalenia. Był to w istocie czas „Młodych”, ale pisarzy nie da się połączyć jedną, wspólną nazwą grupy. Wyłamują się, każdy z nich ma swoją perspektywę, w której postrzega odrębny świat, swój świat i własne pojmowanie żydowskiego losu.

\section{Z jidysz przełożyta i opatrzyta przypisami Bella Szwarcman-Czarnota}

\section{Bibliografia}

\section{1. Źródła}

Fajgenberg Rachela, Dziewczęce lata. Młodość w poleskim sztetlu, tłum. Inka Stempin, wstęp i oprac. Joanna Nalewajko-Kulikov, Warszawa 2021 (w druku). Fajgenberg Rochl, Di kinder-jorn, Warszawa 1909.

Gonshor-Fishman Anna, Kadye Molodowsky in "Literarisze Bleter" (1925-1935): Annotated Bibliography, A Thesis Submitted to the Faculty of Graduate Studies and Research in Partial Fulfillment of the Requirements of the Degree of Master of Arts, McGill University, Montreal 1997.

Molodovsky Kadya, A Jewish Refugee in New York: Rivke Zilberg's Journal, Bloomington 2019.

Molodowski Kadie, A majse fun majn elterzejdns jerusze, „Swiwe” (marzec 1965 kwiecień 1974).

Mołodowska Kadia, Spadek po pradziadku. Opowieść, wstęp, tłum. i oprac. Bella Szwarcman-Czarnota, Warszawa 2021 (w druku).

Paper Bridges: Selected Poems of Kadya Molodowsky, tłum. i oprac. Kathryn Hellerstein, Detroit 1999.

${ }^{24}$ Maharal, akronim od Morejnu ha-Raw Loew (Nasz nauczyciel, raw Loew), właśc. Juda Loew ben Becalel (1520-1609), praski talmudysta, filozof i mistyk. W myśl legendy był twórcą Golema. 


\section{Opracowania}

Dekker Rudolf, Introduction, [w:] Egodocuments and History: Autobiographical Writing in Its Social Context since the Middle Ages, red. Rudolf Dekker, Hilversum 2002.

Kahan-Newman Zelda, Kadya Molodowsky: The Life of a Yiddish Woman Writer, Washington 2018.

Leksikon fun der najer jidiszer literatur, t. 7, red. Efroim Ojerbach i in., Nju Jork 1968. Lisek Joanna, W lustrze pamięci - problemy żydowskiej literatury autobiograficznej, „Autobiografia. Literatura. Kultura. Media” (2017), nr 1.

Marcus Laura, Auto/biographical Discourses: Theory. Criticism. Practice, Manchester-New York 1994.

Pinkas Sluck we-notejha, red. Szimszon Nachmani, Nachum Chonic, Nju Jork-Tel Awiw 1962.

Rawicz Mejlech, Majn leksikon, t. 1, Montreal 1945.

Rejzen Zalmen, Leksikon fun der jidiszer literatur, prese un filologie, t. 3, Wilne 1929. Słownik geograficzny Królestwa Polskiego i innych krajów słowiańskich, red. Filip Sulimierski, Bronisław Chlebowski, Władysław Walewski, t. 1, Warszawa 1880. Słownik geograficzny Królestwa Polskiego i innych krajów słowiańskich, red. Bronisław Chlebowski, Władysław Walewski, t. 10, Warszawa 1889.

Zucker Sheva, Rokhl Faygnberg (1885-1972), Jewish Women's Archive, https://jwa. org/encyclopedia/article/faygnberg-imri-rokhl [dostęp: 15 października 2020]. 